\title{
Kommunalreformens betydning for den kommunale valgdeltagelse
}

\author{
Yosef Bhatti PhD-stipendiat, Institut for Statskundskab, Københavns Universitet \\ Kasper Møller Hansen Professor, Institut for Statskundskab, Københavns Universitet
}

Politologiske studier har vist en negativ, ikke-lineær sammenhæng mellem størrelsen på politiske enheder og valgdeltagelsen til deres repræsentative organer. Det førte til bekymring for den demokratiske deltagelse, da kommunalreformen reducerede antallet af kommuner fra 275 til 98 storkommuner. Debatten blev yderligere aktualiseret, da valgdeltagelsen fra 2005 til 2009 faldt med næsten 4 procentpoint. I denne artikel ser vi nærmere på reformens potentielle betydning for valgdeltagelsen.

\section{Størrelse og demokrati}

Sammenhængen mellem antallet af borgere i fx et land, en bystat, eller en kommune og deres mulighed for at deltage i demokratiet er et klassisk spørgsmål, som har tråde tilbage gennem hele demokratihistorien. I det direkte demokrati kan det være svært for borgeren at komme til orde, når den politiske enhed er stor, og skal alle borgere høres om alle beslutninger, bliver den demokratiske effektivitet lav.

Løsningen på udfordringen har gennem historien været politisk repræsentation. Borgerne vælger repræsentanter eller udtrækkes til demokratisk tjeneste ved lodtrækning som i det græske demokrati (Manin 1997; Hansen 1991). Selvom udbredelsen af det repræsentative demokrati har gjort det praktisk muligt for større politiske enheder at fungere, har det ikke elimineret den demokratiske udfordring ved store enheder. Når vi accepterer det repræsentative demokratis grundprincipper, hvor vælgerne med deres stemme giver mandat til politi- kerne til at styre samfundet i den næste valgperiode, bliver valgdeltagelsen den centrale indikator for demokratiets sundhedstilstand (Beetham 1991; Franklin 2004). Jo højere valgdeltagelse, jo stærkere er politikernes mandat, og desto stærkere er den direkte accept af det repræsentative demokratis måde at fungere på. På den måde er valgdeltagelse ofte fremhævet som en entydig sundhedsindikator for den demokratiske legitimitet (Blondel et al. 1998; Beetham 1994). Imidlertid finder mange studier en negativ sammenhæng mellem valgdeltagelsen og størrelsen på den politiske enhed.

Når nu store enheder kan give demokratiske udfordringer, kan man naturligvis spørge sig selv, hvorfor vi i moderne demokratier ikke blot opererer i små enheder. I det klassiske værk „Size and Democracy“ diskuterer Dahl og Tufte (1973) forholdet mellem demokratiets størrelse (især demos’ størrelse) og henholdsvis den demokratiske legitimitet ( $\mathrm{f}_{\mathrm{X}}$ valgdeltagelse) og demokratiets effektivitet. Den demokratiske legitimitet hos Dahl og Tufte (1973) er knyttet bredt til politisk deltagelse - herunder valgdeltagelse, tillid til politikerne, politisk opmærksomhed mv. - mens demokratiets effektivitet er knyttet til dets evne til at levere sikkerhed i forhold til udefra kommende trusler og skabe mulighed for økonomiske forbedringer. Grundlæggende påpeger Dahl og Tufte (1973), at der er en afvejning mellem demokratisk legitimitet og demokratisk effektivitet. Store enheder styrker den demokratiske effektivitet pga. fx stordriftsfordele, men samtidigt svækkes den demokratiske legitimitet pga. fx lavere valgdeltagelse (Kjær \& Mouritzen 2003). Med David Eastons optik vil man sige, at der er en afvejning mellem effektivt input til det politiske system og effektiv output (Easton 1965). 
Der er således et indbygget dilemma mellem legitimitet og effektivitet i vores repræsentative demokrati.

Afvejningen mellem demokratisk legitimitet og effektivitet blev aktualiseret af kommunalreformen. Hovedargumentet bag reformen var netop ved hjælp af større enheder at indhøste stordriftsfordele og forbedre effektiviteten i kommunerne. Samtidig var der i Strukturkommissionens rapport en erkendelse af, at reformen kunne have betydning for den demokratiske deltagelse, om end effekterne vurderes til at være relativt beskedne (Strukturkommissionen 2004). ${ }^{1}$ Studier kort efter reformen indikerer, at reformen har haft en negativ effekt på den politiske tillid (Lassen \& Serritzlew 2010). I denne artikel ser vi på udviklingen i valgdeltagelsen som en indikator på reformens indflydelse på den demokratiske legitimitet. Spørgsmålet bliver yderligere aktualiseret af, at vi ved kommunalvalget i 2009 havde en valgdeltagelse på 65,8 procent - den laveste valgdeltagelse i 35 år efter en lang periode med stabilitet i den kommunale deltagelse (se figur 1). Det naturlige spørgsmål er, om faldet i valgdeltagelsen skyldes kommunalreformen, eller om andre faktorer kan have været på spil.

Kommunalreformen er naturligvis interessant i sig selv, men også fordi den giver en unik lejlighed til at belyse sammenhængen mellem størrelsen på den politiske enhed og valgdeltagelsen, der som antydet har været så central i demokratihistorien. De fleste undersøgelser er begrænset af, at størrelsen på de politiske enheder er relativt konstant over tid. Ved undersøgelse af kommunalreformen har man 67 sammenlagte enheder (hvis man regner Bornholm med) og 31 uændrede kommuner. Ved at se på om valgdeltagelsen har ændret sig forskelligt i sammenlægnings- og ikke-sammenlægningskommunerne, kan man estimere effekten af de større enheder.

Samlet set søger artiklen at svare på tre tæt relaterede spørgsmål: 1) Er der en sammenhæng mellem indbyggertal og valgdeltagelse i danske kommuner? 2) Har kommunalreformen haft en negativ indflydelse på valgdeltagelsen? 3) Kan kommunalreformen forklare det dramatiske fald i valgdeltagelsen fra 69,5 procent i 2005 til 65,8 procent blot 4 år efter?

Artiklen er opbygget som følger. Efter denne indledning undersøger vi sammenhængen mellem valgdeltagelse og kommunestørrelse ved de fire seneste kommunalvalg i 1997, 2001, 2005 og 2009. Vi finder en stærk sammenhæng mellem de to faktorer. Det er således sandsynligt, at kommunalreformen kunne have en indflydelse, idet den øgede den gennemsnitlige kommunestørrelse væsentligt. I de to efterfølgende afsnit dykker vi længere ned i tallene for at kompensere for to svagheder ved de fleste undersøgelser af sammenhængen mellem valgdeltagelse og kommunestørrelse. Først benytter vi et unikt datasæt på individniveau, der giver bedre lejlighed til at kontrollere for alternative forklaringer såsom kompositionseffekter - altså at store kommuner har en lavere valgdeltagelse, fordi deres borgere har særlige karakteristika ( $\mathrm{f}_{\mathrm{x}}$ flere unge, flere indvandrere, flere tilflyttere mv.). Denne undersøgelse giver os også lejlighed til at vurdere den potentielle betydning af den nedlæggelse af valgsteder, som bl.a. fulgte i kølvandet på kommunalreformen. Vi finder, at sammenlægningskommunerne har lavere deltagelse end ikke-sammenlægningskommuner. Dernæst ser vi på udviklingen i valgdeltagelsen over tid - fra før kommunalreformen til efter. Noget overraskende finder vi, at

Figur 1: Udviklingen i den kommunale valgdeltagelse siden $1970^{2}$

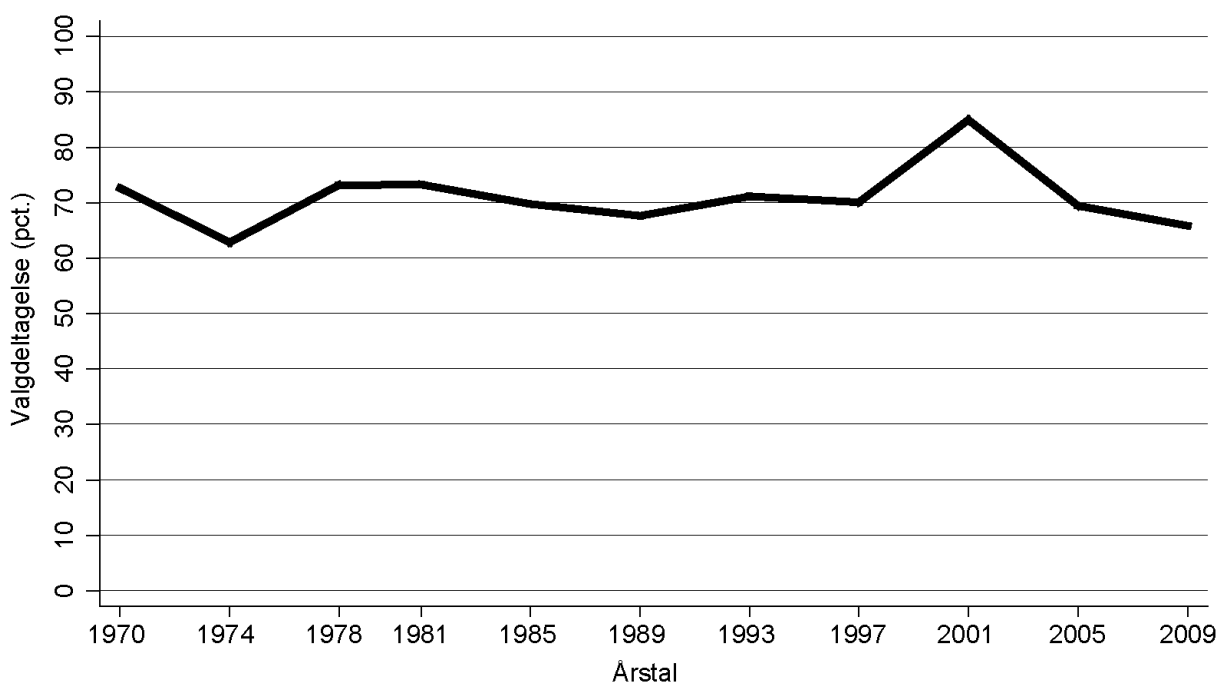


deltagelsen i sammenlægningskommunerne steg i forhold til de øvrige kommuner fra 1997 til 2005, hvorefter de oplevede et fald. Slutteligt samler vi op på analysens fund vedrørende kommunalreformens effekt og diskuterer, om kommunalreformen kan forklare den dramatiske udvikling i valgdeltagelsen fra 2005 til 2009.

\section{Valgdeltagelse og kommunestørrelse}

I Strukturkommissionens betænkning konkluderes det, at man vil kunne forvente et fald i valgdeltagelsen ved større kommuner. Større kommuner kan modvirke følelsen af demokratisk nærhed og kan endvidere betyde, at den enkelte borger har mindre indflydelse (pga. flere borgere pr. mandat). I betænkningen vurderedes det på baggrund af analyser af den kommunale valgdeltagelse i 1997, at man vil kunne forvente et fald i valgdeltagelsen på 2,5 procentpoint, hvis man forøger indbyggertallet i en kommune fra 10.000 til 30.000 . En stigning fra 30.000 til 50.000 indbyggere giver tilsvarende et forventet fald på 1,1 procentpoint, når der er kontrolleret for diverse kommunale socio-demografiske karakteristika (Strukturkommissionen 2004:152). Betænkningen forventer altså et fald i valgdeltagelsen ved større kommuner, men at dette fald ikke vil være lineært i relation til den nye kommunestørrelse - faldet forventes at være størst for de små og mindst for de større sammenlægningskommuner.

Flere studier bekræfter strukturkommissionen konklusioner for kommunalvalgene i 1993 og i 1997 (Mouritzen 1997; Frandsen 2004; Juul-Madsen \& Skou 2006). Den negative, ikke-lineære effekt er ofte opererationaliseret ved at anvende logaritmen til antal indbygger $\mathrm{i}$ kommunen i sammenhæng med valgdeltagelsen. I figur 2 analyseres således den bivariate sammenhæng mellem den naturlige logaritme til indbyggertallet og valgdeltagelsen ved de fire kommunalvalg fra 1997 til 2009. I analyserne bekræftes den negative og ikke-lineære effekt af indbyggertallet på valgdeltagelsen for alle fire valg. ${ }^{3}$

Figur 2: Bivariat sammenhæng mellem valgdeltagelsen og indbyggertal (kommuneniveau)

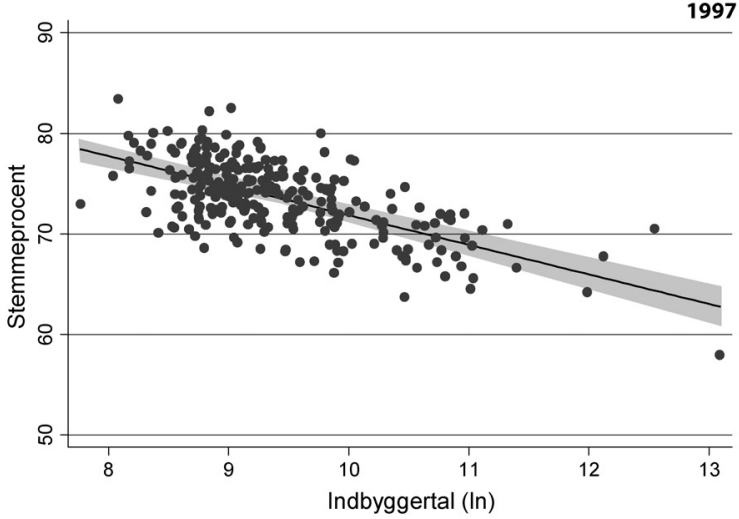

Regressionslinje: $y=101,3-2,94^{*} x, R^{\wedge} 2=0,408$

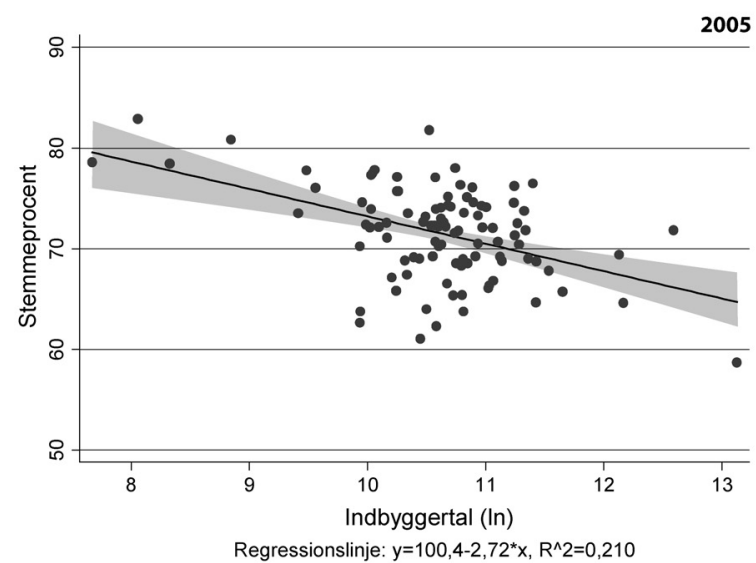

997

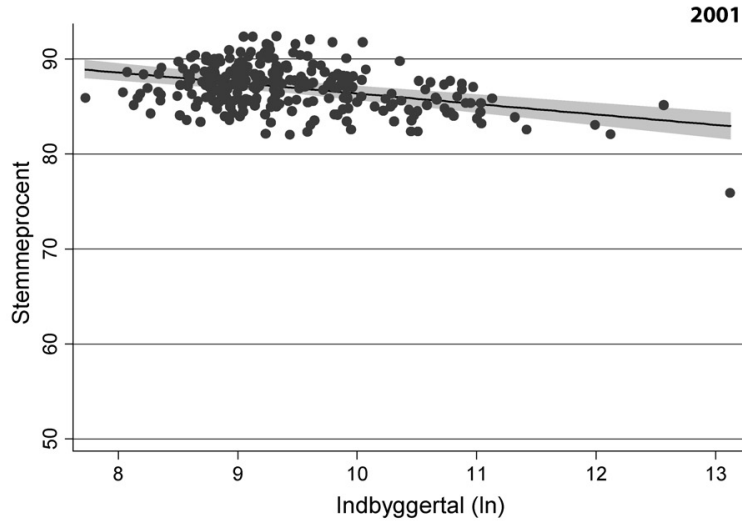

Regressionslinje: $y=97,38-1,10^{*} x, R^{\wedge} 2=0,145$

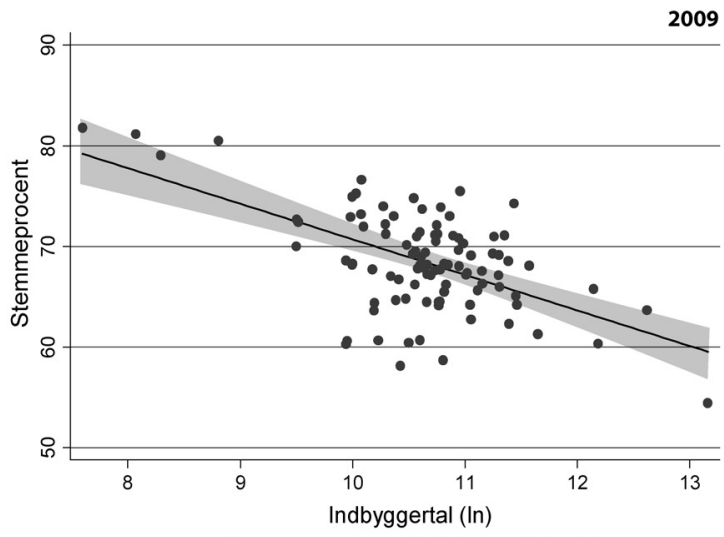

Regressionslinje: $y=106,0-3,53^{*} x, R^{\wedge} 2=0,314$

Note: Det grå område er et $95 \%$ konfidensinterval for regressionens forudsagte valgdeltagelse. Omregning af den logaritme skala til antal indbyggere svarer til $\operatorname{eksp}(8)=2.981, \operatorname{eksp}(9)=8.103, \operatorname{eksp}(10)=22.026, \operatorname{eksp}(11)=59.874, \operatorname{eksp}(12)=162.754 \&$ eksp(12) $=442.413$ indbyggere 
I alle fire regressioner i figur 2 kan vi se den forventede negative sammenhæng mellem indbyggertal og valgdeltagelse både før og efter kommunalreformen. Skalaen på indbyggertal er (naturlig) logaritmisk, hvorfor sammenhængen er stærkest for små kommuner. Et spring fra 8 til 9 på den logaritmiske skala svarer til et spring fra ca. 3.000 indbyggere til ca. 8.000, mens et spring fra 11 til 12 svarer til en ændring fra ca. 60.000 indbyggere til 163.000 (man omregner et tal, $\mathrm{x}$, fra den naturlige logaritmiske skala ved at tage eksp(x) eller $2,72^{\wedge} \mathrm{x}$ ). Effekten er altså størst for de små kommuner. Dette giver intuitiv mening, idet 1.000 indbyggere ekstra sandsynligvis betyder mere for følelsen af demokratisk nærhed, når man går fra 3.000 til 4.000 indbyggere, end hvis man går fra 60.000 til 61.000 .

Den negative effekt af antallet af indbyggere (dvs. hældningen på linjen) er mindst i 2001, hvor det kombinerede folketingsvalg og kommunalvalg fandt sted. Tidligere studier har vist, at demografiske faktorer som alder, civilstatus og kommunal bopælsanciennitet har større effekt på valgdeltagelsen ved kommunalvalg, end det er tilfældet ved folketingsvalg, der så at sige trækker svage grupper op fra sofaen (Elklit et al. 2007). Det vil sige, at der sker en polarisering af vælgerkorpset ved kommunalvalg i forhold til folketingsvalg i relation til valgdeltagelsen (se også Elklit et al. 2005; Bhatti \& Hansen 2010).

De bivariate analyser i figur 2 tager naturligvis ikke højde for, at der er demografiske forskelle mellem små og store kommuner. Fx er der flere unge, flere enlige og flere personer med udenlandsk baggrund i store kommuner (Elklit et al 2007: 81). Og da disse grupper stemmer markant mindre end andre demografiske grupper, kan de bivariate effekter blot være udtryk for en spuriøs sammenhæng, som forsvinder, når vi kontrollerer for kommunernes demografiske sammensætning. I tabel 1 kontrollerer vi for en række kommunale karakteristika, som i tidligere analyser har vist sig af have effekt (Mouritzen 1997; Frandsen 2004; Juul-Madsen \& Skou 2006). Da vi anvender OLS regression, skal en koefficient tolkes som effekten på valgdeltagelsen i procentpoint, når den pågældende uafhængige variabel stiger med en enhed, samtidig med at alle de øvrige uafhængige variable holdes konstante. ${ }^{45}$

Det vigtigste fund i regressionerne i tabel $1 \mathrm{er}$, at den negative, ikke-lineær effekt af antallet af indbyggere på den kommunale valgdeltagelse ikke forsvinder, når vi kontrollerer for effekten af kommunens demografiske karakteristika. Antallet af indbyggere påvirker altså valgdeltagelsen i negativ retning. Vi eksperimenterede med en lang række alternative specifikationer af indbyggertalsvariablen - herunder en lineær funktionel form og en serie af dummy-variable, men som tidligere studier finder vi, at
Tabel 1: Valgdeltagelsen (pct.) som funktion af kommunale karakteristika (1997 til 2009)

\begin{tabular}{|c|c|c|c|c|}
\hline & 1997 & 2001 & 2005 & 2009 \\
\hline Antal indbyggere (In) & $\begin{array}{l}-3,59^{* \star *} \\
(0,56)\end{array}$ & $\begin{array}{l}-0,94^{\star * *} \\
(0,27)\end{array}$ & $\begin{array}{l}-1,90^{*} \\
(0,76)\end{array}$ & $\begin{array}{l}-1,94^{*} \\
(0,77)\end{array}$ \\
\hline Sammenlægningskommune & $\begin{array}{l}-0,66 \\
(0,67)\end{array}$ & $\begin{array}{l}-0,49 \\
(0,34)\end{array}$ & $\begin{array}{r}0,14 \\
(1,15)\end{array}$ & $\begin{array}{l}-1,37 \\
(1,10)\end{array}$ \\
\hline 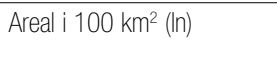 & 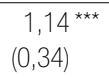 & $\begin{array}{c}0,35^{*} \\
(0,16)\end{array}$ & $\begin{array}{c}1,23^{*} \\
(0,59)\end{array}$ & $\begin{array}{r}0,91 \\
(0,58)\end{array}$ \\
\hline $\begin{array}{l}\text { Indbyggere (1.000) pr. } \\
\text { mandat }\end{array}$ & $\begin{array}{r}0,27 \\
(0,42)\end{array}$ & $\begin{array}{l}-0,31 \\
(0,21)\end{array}$ & $\begin{array}{l}-0,23 \\
(0,59)\end{array}$ & $\begin{array}{l}-0,61 \\
(0,54)\end{array}$ \\
\hline $\begin{array}{l}\text { Beskatningsgrundlag i } \\
100.000 \text { kr. pr. indbygger }\end{array}$ & $\begin{array}{l}-4,62^{*} \\
(2,20)\end{array}$ & $\begin{array}{l}-0,14 \\
(0,71)\end{array}$ & $\begin{array}{l}-4,79 * \\
(2,40)\end{array}$ & $\begin{array}{l}-2,37 \\
(2,36)\end{array}$ \\
\hline $\begin{array}{l}\text { Procent (100) almene } \\
\text { boliger af alle boliger }\end{array}$ & $\begin{array}{r}1,59 \\
(2,78)\end{array}$ & $\begin{array}{r}1,75 \\
(1,42)\end{array}$ & $\begin{array}{l}-5,04 \\
(4,17)\end{array}$ & $\begin{array}{l}-8,11^{*} \\
(4,05)\end{array}$ \\
\hline $\begin{array}{l}\text { Udg. til førtidspen. pr. } \\
\text { 14-64/66 årig i } 1.000 \text { kr. }\end{array}$ & $\begin{array}{l}-0,37 \\
(0,29)\end{array}$ & $\begin{array}{l}-0,31^{\text {** }} \\
(0,11)\end{array}$ & $\begin{array}{r}0,21 \\
(0,28)\end{array}$ & $\begin{array}{r}0,20 \\
(0,16)\end{array}$ \\
\hline $\begin{array}{l}\text { Udg. til kontanthiæ. pr. } \\
\text { 14-64/66 årig i } 1.000 \text { kr. }\end{array}$ & $\begin{array}{l}-0,24 \\
(0,22)\end{array}$ & $\begin{array}{r}-0,086 \\
(0,10)\end{array}$ & $\begin{array}{l}-0,85^{*} \\
(0,38)\end{array}$ & $\begin{array}{l}-1,35^{\star *} \\
(0,45)\end{array}$ \\
\hline $\begin{array}{l}\text { Andel +15 årige med } \\
\text { grunduddannelse }\end{array}$ & $\begin{array}{l}-28,8^{* * *} \\
(4,85)\end{array}$ & $\begin{array}{l}-17,4^{\text {** }} \\
(2,49)\end{array}$ & $\begin{array}{l}-41,6^{\star \star *} \\
(11,7)\end{array}$ & $\begin{array}{l}-30,9^{*} \\
(11,8)\end{array}$ \\
\hline Andel 18-29 årige vælgere & $\begin{array}{l}-26,9^{\star *} \\
(8,64)\end{array}$ & $\begin{array}{l}-9,28^{*} \\
(4,50)\end{array}$ & $\begin{array}{l}-31,1 \\
(19,0)\end{array}$ & $\begin{array}{l}-16,1 \\
(18,5)\end{array}$ \\
\hline Andel +80 årige vælgere & $\begin{array}{l}-3,18 \\
(13,7)\end{array}$ & $\begin{array}{l}-58,4^{* * *} \\
(6,58)\end{array}$ & $\begin{array}{r}7,02 \\
(25,0)\end{array}$ & $\begin{array}{l}-0,10 \\
(26,8)\end{array}$ \\
\hline Andel nydanskere & $\begin{array}{l}-4,19 \\
(9,66)\end{array}$ & $\begin{array}{l}-35,3^{\star \star *} \\
(4,49)\end{array}$ & $\begin{array}{r}0,0081 \\
(15,2)\end{array}$ & $\begin{array}{l}-9,35 \\
(13,1)\end{array}$ \\
\hline Konstant & $\begin{array}{l}131,0^{* * *} \\
(6,24)\end{array}$ & $\begin{array}{l}110,9^{\text {***}} \\
(2,91)\end{array}$ & $\begin{array}{l}118,9^{* \star *} \\
(9,26)\end{array}$ & $\begin{array}{l}110,9^{\star * \star} \\
(8,85)\end{array}$ \\
\hline$N$ & 275 & 275 & 98 & 98 \\
\hline F-test & 27,33 & 56,07 & 14,07 & 17,83 \\
\hline $\mathrm{R}^{2}$ & 0,556 & 0,720 & 0,665 & 0,716 \\
\hline Justeret $R^{2}$ & 0,536 & 0,707 & 0,618 & 0,676 \\
\hline
\end{tabular}

Note: $+\mathrm{p}<0,10 ;{ }^{*} \mathrm{p}<0,05 ;{ }^{* *} \mathrm{p}<0,01 ;{ }^{* * *} \mathrm{p}<0,001$. OLS regression, Ustandardiseret betakoefficienter med deres standardfejl i parentes.

den naturlige logaritmiske funktionelle form er den, der bedst beskriver den partielle sammenhæng.

Det er værd at bemærke, at indbyggertal er signifikant ved alle fire valg, hvilket tyder på, at sammenhængen er robust over tid. Sammenligner vi koefficienterne for antallet af indbyggere i tabel 1 med de tilsvarende bivariate koefficienter i figur 2 , kan vi også se, at sammenhængene 
i enkelte år er lidt svagere (i 2001, 2005 og 2009) og lidt stærkere i 1997, når vi kontrollerer for kommunale karakteristika. Det er altså ikke entydigt, at kontrol for kommunale karakteristika svækker sammenhængen mellem størrelse og valgdeltagelse.

Substantielt er de partielle effekter betydelige. En ændring $\mathrm{i}$ indbyggertallet fra 10.000 indbyggere til 30.000 indbyggere (hvilket svarer til at gå fra $\ln (10.000)=9,21$ til $\ln (30.000)=10,31$ på den logaritmiske skala) implicerer en effekt på valgdeltagelsen på $-3,9$ procentpoint i 1997 , $-1,0$ procentpoint i 2001, -2,1 procentpoint i 2005 og $-2,1$ procentpoint i 2009 eller ganske tæt på de $-2,5$ procentpoint, som Strukturkommissionen beregnede. Den tilsvarende effekt for en ændring fra 30.000 til 50.000 $(\ln (50000)=10,81$ på den logaritmiske skala), implicerer effekter på henholdsvis $-1,8 ;-0,5 ;-1,0$ og $-1,0$ procentpoint - igen ganske tæt på Strukturkommissionens estimat på $-1,1$ procentpoint.

Sammenlægningsvariablen er insignifikant $i$ alle fire modeller. Der er en tendens til, at koefficienten bevæger sig i negativ retning i 2009, men bevægelsen er langt mindre end den statistiske usikkerhed. Udover den negative effekt af antallet af indbygger på valgdeltagelse og den insignifikante sammenlægningsvariabel, har de fleste kontrolvariable den forventede retning. Areal er positivt, eftersom valgdeltagelsen er større i landkommuner end bykommuner (modellen kontrollerer for indbyggertal, hvorfor arealet reelt siger noget om befolkningstætheden). Vi anvender den naturlige logaritme til areal, som ved indbyggertal, hvilket viser, at der er en større positiv effekt på valgdeltagelsen af at gå fra små til mellemstore kommuner end fra mellemstore til de helt store kommuner. Kommuner, der har mange borgere med socio-demografiske karakteristika, som vi ved hænger sammen med en lav politisk deltagelse (fx Elklit et al. 2005; Bhatti \& Hansen 2010), tenderer til at klare sig dårligt, hvad angår valgdeltagelsen. Dette gælder fx nydanske borgere, borgere med kun grunduddannelse, unge, ældre og borgere på sociale overførsler. Det skal understreges, at man ikke fra tabel 1 kausalt kan slutte, at borgere med de pågældende individuelle karakteristika har lavere valgdeltagelse end andre grundet risikoen for økologiske fejlslutninger.

Ovenstående analyse bekræfter de fund, som blev angivet i Strukturkommissionens rapport. Der er en negativ sammenhæng mellem indbyggertal og valgdeltagelse, og sammenhængen er betydelig i de indbyggertal-intervaller, hvor de fleste sammenlægninger skete. Der er således god grund til at forvente, at kommunalreformen kunne føre til faldende valgdeltagelse. For at undersøge om det skete i praksis, gennemfører vi to yderligere analyser. Først anvender vi et unikt individdatasæt til at undersøge, om sammenlægningskommuner havde lavere valgdeltagelse end ikke-sammenlægningskommuner i 2009. Fordelen ved dette datasæt er, at det tillader bedre kontroller end det ovenstående, da data er langt mere informationsrigt og ikke mindst på individniveau, modsat ovenstående, som er på kommuneniveau. Dernæst anvender vi paneldata på kommuneniveau til at se på forskellen fra før til efter kommunalreformen. Fordelen ved en sådan analyse er, at den ser direkte på andringen i valgdeltagelse. Vi kan således udelukke at en evt. effekt skyldes uobserverede uafhængige variable, der er konstante over tid.

\section{Stemmer borgere i sammenlægnings kommuner mindre end ikke-sammenlægningskommuner?}

For at undersøge om valgdeltagelsen var højere i sammenlægningskommuner ved valget i 2009 , anvender vi et individdatasæt med omkring 2,3 mio. stemmeberettigede danskere. Ved kommunalvalget i 2009 blev valglisterne i 44 kommuner samkørt med socio-demografiske data fra Danmarks Statistik (Bhatti \& Hansen 2010). Desuden har vi kodet, om borgeren boede i en sammenlægningskommune eller ej. Fordelen ved datasættet i forhold til det ovenstående er først og fremmest, at vi har meget detaljerede data, hvorfor vi kan kontrollere irrelevant variation bedre væk. Desuden har vi mulighed for at undersøge effekten af de enkelte borgeres afstand (målt i fugleflugt) til rådhuset. Vi inddrager også borgerens afstand til valgstedet for at undersøge, om lukninger af valgsteder kan tænkes at have haft betydning for valgdeltagelsen. Endelig er data på individniveau, hvorfor vi også kan vurdere effekten af kontrolvariablene uden at risikere økologiske fejlslutninger.

Resultaterne af analysen findes i tabel 2. Da den afhængige variabel nu er binær (om at individet stemte eller ikke stemte), anvendes en binomial logistisk regression. Standardfejlene er klustrede på kommuneniveau for at sikre, at vi ikke overvurderer vores sikkerhed omkring variablene på kommuneniveau (Primo et al. 2007). I den venstre resultatkolonne har vi de ustandardiserede logistiske koefficienter. En positiv koefficient angiver en positiv sammenhæng mellem den pågældende variabel og sandsynligheden for at et individ stemmer og omvendt for en negativ koefficient. Da størrelsen af effekterne kan være svære at tolke ud fra den logistiske koefficient alene, har vi til højere angivet to effektmål. På venstre side af skråstregen ses effekten på valgdeltagelsen i procentpoint af at gå fra en halv standardafvigelse under den uafhængige variabels middelværdi til en halv standardafvigelse over, når alle andre variable holdes konstant på deres middelværdi. ${ }^{6}$ På højre side af skråstregen ses effekten i procentpoint af at gå fra 0 til 1 på dummyvariable. Fx vurderes effekten af at være en mand i forhold til at være en kvinde at være -1 procentpoint. Kvinder stemmer altså i gennemsnit 1 
Tabel 2: Valgdeltagelsen som funktion af udvalgte demografiske variable - Binær logistisk regression.

\begin{tabular}{|c|c|c|}
\hline & Logistisk koef. & $+/-1 / 2 \mathrm{SD} / 0=>1$ \\
\hline Sammenlægningskommune & $\begin{array}{l}-0,17^{* *} \\
(0,06)\end{array}$ & $-2 /-3$ \\
\hline Afstand til afstemningssted (meter, In) & $\begin{array}{l}-0,46^{* * *} \\
(0,04)\end{array}$ & $-/-$ \\
\hline Afstand til afstemningssted (meter, In) ${ }^{2}$ & $\begin{array}{l}0,03^{* * *} \\
(0,00)\end{array}$ & $-1-$ \\
\hline Afstand til rådhus (meter, In) & $\begin{array}{l}-0,01 \\
(0,10)\end{array}$ & $-/-$ \\
\hline Afstand til rådhus (meter, In) $)^{2}$ & $\begin{array}{r}0,00 \\
(0,01)\end{array}$ & $-/-$ \\
\hline Antal indbyggere i kommunen (In) & $\begin{array}{l}-0,17^{* * *} \\
(0,02)\end{array}$ & $-3 /-$ \\
\hline Areal af kommunen $\left(\mathrm{km}^{2}, \mathrm{ln}\right)$ & $\begin{array}{l}0,08 \\
(0,02)\end{array}$ & 2/- \\
\hline Mand & $\begin{array}{l}-0,06^{* * *} \\
(0,01)\end{array}$ & $-1 /-1$ \\
\hline Alder i 1.000 dage & $\begin{array}{l}0,13^{* * *} \\
(0,01)\end{array}$ & 18/- \\
\hline Alder i 1.000 dage $^{2}$ & $\begin{array}{l}-0,00^{* * *} \\
(0,00)\end{array}$ & $-11 /-$ \\
\hline Igangværende grundskole & $\begin{array}{l}0,98 \text { *** } \\
(0,05)\end{array}$ & $1 / 16$ \\
\hline Igangværende gymnasial uddannelse & $\begin{array}{l}1,49^{* * *} \\
(0,06)\end{array}$ & $5 / 21$ \\
\hline Igangværende faglig uddannelse & $\begin{array}{l}0,20 \\
(0,05)\end{array}$ & $1 / 4$ \\
\hline Igangværende kort- \& ml. videregå. udd. & $\begin{array}{l}0,61^{* * *} \\
(0,02)\end{array}$ & $3 / 11$ \\
\hline Igangværende lang videregående udd. & $\begin{array}{l}0,566^{* * *} \\
(0,04)\end{array}$ & $2 / 10$ \\
\hline Gymnasial uddannelse & $\begin{array}{l}0,72^{* * *} \\
(0,02)\end{array}$ & $5 / 13$ \\
\hline Faglig uddannelse & $\begin{array}{l}0,33^{* * *} \\
(0,01)\end{array}$ & $3 / 7$ \\
\hline Kort- og melleml. videregående udd. & $\begin{array}{l}0,92 * * * \\
(0,01)\end{array}$ & $8 / 17$ \\
\hline Lang videregående udd. & $\begin{array}{l}1,18 \text { *** } \\
(0,05)\end{array}$ & $7 / 19$ \\
\hline Indkomst i 100.000 & $\begin{array}{l}0,00 * \\
(0,00)\end{array}$ & $0 /-$ \\
\hline I arbejde & $\begin{array}{l}0,23^{* * *} \\
(0,01)\end{array}$ & $2 / 5$ \\
\hline Etnisk dansk gift & $\begin{array}{l}0,62^{* * *} \\
(0,01)\end{array}$ & $6 / 13$ \\
\hline Gift med person fra Vest-Europa & $\begin{array}{l}0,15^{* * *} \\
(0,02)\end{array}$ & $0 / 3$ \\
\hline Gift med person fra ikke-vestlig land & $\begin{array}{l}0,28 \text { *** } \\
(0,02)\end{array}$ & $1 / 5$ \\
\hline Herkomst vestlige lande & $\begin{array}{l}-0,55^{* * *} \\
(0,04)\end{array}$ & $-2 /-12$ \\
\hline Herkomst ikke-vestlige lande & $\begin{array}{l}-0,82^{* * *} \\
(0,07)\end{array}$ & $-4 /-19$ \\
\hline Statsborger vestlige lande & $\begin{array}{l}-0,566^{* * *} \\
(0,02)\end{array}$ & $-1 /-13$ \\
\hline Statsborger ikke-vestlige lande & $\begin{array}{l}-0,23^{* * *} \\
(0,06)\end{array}$ & $-1 /-5$ \\
\hline Adresseanciennitet i 1.000 dage & $\begin{array}{l}0,03^{* * *} \\
(0,00)\end{array}$ & 3/- \\
\hline $\begin{array}{l}\text { Kommunalanciennitet i } 1.000 \text { dage } \\
\text { Konstant }\end{array}$ & $\begin{array}{l}0,011^{* * *} \\
(0,00) \\
2,05 * * \\
(0,65)\end{array}$ & $1 /-$ \\
\hline Antal stemmeberettigede & 2.196 .512 & \\
\hline McFadden pseudo $\mathrm{R} \wedge 2$ & 0,10 & \\
\hline Log likelihood & -1.260 .153 & \\
\hline Chi^2 & $279.623,01$ & \\
\hline
\end{tabular}

procentpoint mere end mænd, når der tages højde for de $ø$ vrige variable.

Det vigtigste resultat i tabel $2 \mathrm{er}$, at effekten af at bo i en sammenlægningskommune estimeres til at være negativ. Borgere, der bor i en sammenlægningskommune, har 3 procentpoint lavere valgdeltagelse end de øvrige borgere, når man tager højde for de øvrige karakteristika. Dette tyder alt andet lige på, at kommunalreformen kan have haft en negativ effekt på valgdeltagelsen. Areal og indbyggertal har samme retning som i kommuneregressionerne (tabel 1). Store (ikke befolkningstætte) kommuner har en høj valgdeltagelse, mens det modsatte gælder kommuner med et højt indbyggertal.

Effekten af sammenlægning er ikke det eneste interessante resultat. Vi ser også, at logaritmen af afstanden til valgstedet er negativ. Det implicerer altså, at borgere der bor langt fra et valgsted har en lavere tendens til at stemme, end borgere der bor tættere på. Det er i god overensstemmelse med den rationelle litteratur om valgdeltagelse, hvor omkostningerne ved at stemme, er afgørende for individets beslutning om at benytte sin stemmeret ( $\mathrm{f}_{\mathrm{x}}$ Riker \& Ordeshook 1968). Er der langt til valgstedet, er det mere besværligt at stemme, og det kan alt andet lige være mere fristende for personer, der er i tvivl om, hvorvidt de vil stemme, at blive hjemme. ${ }^{7} \mathrm{Da}$ der er tale om en logaritmisk effekt, er betydningen af en meter ekstra til valgstedet størst, når man bor tæt på. Vi har også medtaget logaritmen til distancen i anden, som er positiv, hvilket implicerer, at effekten falder hurtigere, end man ville kunne forvente ud fra den logaritmiske funktionelle form alene. Effekten er stor, hvis man har kort afstand til valgstedet. Fx er forskellen i forventet sandsynlighed for deltagelse et fald på 1,5 procentpoint, hvis man går fra at have 500 meter til at have $1 \mathrm{~km}$ til valgstedet. Fra $1 \mathrm{~km}$ til $2 \mathrm{~km}$ er faldet kun omkring 0,7 procentpoint. Afstanden på over $2 \mathrm{~km}$ har stort set ingen effekt på valgdeltagelsen. En umiddelbar policy implikation af at afstanden til valgstedet påvirker valgdeltagelsen negativt (i intervallet $0-2 \mathrm{~km})$ er, at man kan øge valgdeltagelsen ved at gøre det muligt at stemme endnu flere steder - en gevinst man især vil opnå i tætbefolkede områder.

Robuste standardfejl klusterede på kommuneniveau i parentes. Referencekategorier: Ikke i gang med en uddannelse, Grundskole, Ikke gift, Dansk herkomst og Dansk statsborger. Effekten i kolonnen efter den logistiske koefficient er den procentvise effekt af at ændre variablen en halv standardafvigelse under gennemsnittet til en halv standardafvigelse over gennemsnittet, når de andre variable holdes konstant på deres gennemsnit og for kategoriske variable den procentvise effekt af at gå fra referencekategorien til variablen (De kvadrerede variable holdes konstant på førsteleddet $\mathrm{i}$ andet). " $\mathrm{p}<0,05$; " $\mathrm{p}<0,01 ;{ }^{* * *} \mathrm{p}<0,001$. 
Betydningen af afstanden til valgstederne er interessant i sig selv, men også fordi kommunalreformen har bidraget til en betydelig nedlæggelse af valgsteder, og derved at gennemsnitsafstanden til valgstederne er blevet øget. Det er således tænkeligt, at reformen også kunne have en (om end lille) indirekte effekt gennem afstanden til valgstederne (bemærk dog at der også har været betydelige nedlæggelser før reformen).

Udover afstanden til valgstederne indeholder tabel 2 koefficienter for afstanden til rådhuset i de nye kommuner. Koefficienterne er insignifikante. Der synes altså ikke at være en forskel mellem valgdeltagelsen mellem center og periferi i de nye kommuner. Center og periferi i kommunerne er altså mobiliseret i samme udstrækning som ved valget i 2009, hvorfor analysen ikke kan bekræfter de velbegrundede formodninger, der har været fremført om det modsatte (fx Kjær 2009; Løhmann 2010).

De mange kontrolvariable er alle signifikante og i den forventede retning. Kvinder stemmer mere end mænd (Bhatti \& Hansen 2010). Der er en kurvelineær sammenhæng mellem alder og valgdeltagelse, hvor unge og ældre stemmer mindst og de midaldrende mest. Borgere i uddannelse stemmer mere end borgere, der ikke er i uddannelse, og en høj gennemført uddannelse bidrager også positivt til valgdeltagelsen. Indkomst har nogen - om end en meget beskeden - effekt, mens effekten af at være i arbejde er større. Også ens civilstand er af betydning. At være gift har en positiv effekt - især hvis man er gift med en person af dansk herkomst. Som tidligere undersøgelser har vist (fx Elklit et al. 2005), har etniske danskere betydelig højere valgdeltagelse end nydanskere. Endelig har borgernes bopælsstabilitet betydning, således at de mest stabile er dem, der stemmer mest.

Samlet set indikerer individanalysen for 2009, at kommunalreformen kan have haft betydning. Valgdeltagelsen er lavere (ca. 3 procentpoint) i sammenlægningskommunerne, selv når man tager højde for de mange individ- og kommunevariable i modellen. Samtidig kan reformen have haft en indirekte effekt gennem lukningen af valgsteder, hvilket kan have gjort den gennemsnitlige omkostning ved at stemme større. Styrken ved individanalysen er, at vi kan tage højde for langt flere forhold end de øvrige analyser i denne artikel og at vi undgår faren for økologiske fejlslutninger. Svagheden er, at den er statisk - vi har ikke individpanel data. I næste afsnit undersøger vi dynamisk, om de sammenlagte kommuner har fået lavere valgdeltagelse over tid i forhold til ikkesammenlægningskommunerne. Fordelen ved en sådan analyse er, at den garderer imod uobserverede variable, der er konstante over tid.

\section{Er ændringen i valgdeltagelsen forskellig i sammenlægnings- og ikke-sammenlægnings- kommuner?}

I denne sidste del af analysen ser vi på udviklingen over tid. Vi undersøger tre perioder - 1997-2005, 2005-2009 og 1997-2009. Fravalget af valget i 2001 skyldes, at det som tidligere omtalt blev afholdt samtidig med et folketingsvalg, hvorfor valgdeltagelsen afveg fra normen ved kommunalvalg. 2005-valget var det første valg, hvor der blev stemt i de nye kommuner, mens reformen først var trådt endelig i kraft ved 2009-valget. Vi undersøger derfor både udviklingen fra 1997 til 2005 og 2009, da det er uklart, hvornår en evt. effekt kunne slå igennem.

I analysen er forskellen mellem valgdeltagelsen i den undersøgte periode den afhængige variabel. Fx i 19972005 analysen ser vi på, hvordan valgdeltagelsen har udviklet sig forskelligt i de enkelte kommuner fra valget $\mathrm{i}$ 1997 til valget i 2005 . Hvis valgdeltagelsen i kommunen er gået frem, er den afhængige variabel positiv, og hvis valgdeltagelsen i kommunen er gået tilbage, er den negativ. Valgdeltagelsen for 1997 og 2001 er aggregeret til de nye kommuner ved at summere antal afgivne stemmer og antal stemmeberettigede i de kommuner, der endte med at gå sammen. Den vigtigste uafhængige variabel er en dummy-variabel, som angiver, hvorvidt kommunen er en sammenlægningskommune.

Udover at kunne bidrage til studiet om kommunalreformens effekt, er analysen interessant i en metodisk sammenhæng, fordi vi har at gøre med en afart af et naturligt eksperiment for betydningen af kommunestørrelse, hvor sammenlægning / ikke-sammenlægningskommune fungerer som den eksogene påvirkning. Der er dog i grænser for "naturligheden“ af eksperimentet, da kommunalreformen ikke er en randomiseret stimuli, idet mindre kommuner sammenlægger sig oftere end større. Derfor er det ekstra vigtigt at kontrollere for tredjevariable og især kommunestørrelse, da størrelse er tæt forbundet med sammenlægning.

Da der er tale om en OLS regression, er tolkningen som i tabel 1, blot har vi nu at gøre med effekten af enhed på de uafhængige variable på en ændring (i procentpoint) af valgdeltagelsen. ${ }^{8}$

Tabel 3 indikerer, at sammenlægningskommunerne faktisk fik højere valgdeltagelse mellem 1997 og 2005 (1,5-2,0 procentpoint) både bivariat og multivariat. Omvendt var der mellem 2005-2009 som forventet et fald på omkring 2 procentpoint, mens effekten for hele perioden (1997-2009) ikke er signifikant. Mængden af kontrolvariable i forhold til cases bevirker stor multikollinearitet, hvorfor kun få af kontrolvariablene er forskellig for 0 , men for sammenlægningsvariablene er multikollinearite- 
Tabel 3: Ændringen i valgdeltagelse som funktion af sammenlægningskommune samt demografiske variable

\begin{tabular}{|c|c|c|c|c|c|c|}
\hline & \multicolumn{2}{|c|}{ 1997-2005 } & \multicolumn{2}{|c|}{ 2005-2009 } & \multicolumn{2}{|c|}{ 1997-2009 } \\
\hline $\begin{array}{l}\text { Sammenlægningskommune } \\
\text { Antal indbyggere (In) } \\
\text { Areal i } 100 \mathrm{~km}^{2} \text { (In) } \\
\text { Indbyggere (1.000) pr. mandat } \\
\text { Beskatningsgrundlag i 100.000 kr. pr. indbygger } \\
\text { Procent (100) almene boliger af alle boliger } \\
\text { Udg. til førtidspen. pr. 14-64/66 årig i } 1.000 \mathrm{kr} \text {. } \\
\text { Udg. til kontanthiæ. pr. 14-64/66 årig i } 1.000 \mathrm{kr} \text {. } \\
\text { Andel +15årige med grunduddannelse } \\
\text { Andel } 18 \text {-29 årige vælgere } \\
\text { Andel +80 årige vælgere } \\
\text { Andel nydanskere } \\
\text { Endring i beskatningsgrundlag i 100.000 pr. indbygger } \\
\text { Endring i procent (100) almene boliger af alle boliger } \\
\text { Endring i udg. til førtidspen. pr. 14-64/66 årig i } 1.000 \mathrm{kr} \text {. } \\
\text { Endring i udg. til kontanthiæ. pr. 14-64/66 årig i } 1.000 \mathrm{kr} \text {. } \\
\text { Endring i andel med grunduddannelse } \\
\text { Endring i andel unge vælgere } \\
\text { Endring i andel gamle vælgere } \\
\text { Endring i andel indvandrere } \\
\text { Konstant }\end{array}$ & $\begin{array}{l}-1,81^{\star \star \star} \\
(0,38)\end{array}$ & $\begin{array}{l}1,78^{\star} \\
(0,72) \\
-0,50 \\
(0,52) \\
-0,87^{\star} \\
(0,41) \\
0,85^{\star} \\
(0,38) \\
-3,52 \\
(3,77) \\
-2,75 \\
(3,49) \\
-0,29 \\
(0,44) \\
-0,38 \\
(0,33) \\
3,95 \\
(7,66) \\
26,4+ \\
(14,5) \\
52,3^{*} \\
(23,4) \\
-14,1 \\
(13,2) \\
5,28 \\
(7,72) \\
13,5 \\
(19,4) \\
0,42 \\
(0,61) \\
-0,16 \\
(0,35) \\
24,7 \\
(29,0) \\
-79,6^{\star *} \\
(25,8) \\
48,5 \\
(52,3) \\
-37,8 \\
(48,3) \\
-0,50 \\
(7,59)\end{array}$ & $\begin{array}{l}-2,24^{\star \star \star} \\
(0,39)\end{array}$ & $\begin{array}{c}-2,06^{*} \\
(0,80) \\
-0,38 \\
(0,61) \\
-0,24 \\
(0,43) \\
-0,90^{*} \\
(0,41) \\
3,73+ \\
(2,10) \\
-0,68 \\
(3,91) \\
0,37 \\
(0,23) \\
-0,24 \\
(0,35) \\
12,0 \\
(8,84) \\
47,1^{*} \\
(16,6) \\
6,13 \\
(26,3) \\
-12,7 \\
(11,6) \\
-9,75 \\
(7,41) \\
13,9 \\
(17,9) \\
-0,48 \\
(0,49) \\
0,45 \\
(0,38) \\
-12,6 \\
(50,6) \\
-109,0^{*} \\
(52,4) \\
-178,2 \\
(108,4) \\
-73,2 \\
(47,7) \\
-11,0 \\
(7,91)\end{array}$ & $\begin{array}{l}-4,05^{\star \star \star} \\
(0,55)\end{array}$ & $\begin{array}{c}0,029 \\
(0,95) \\
-0,32 \\
(0,75) \\
-1,31^{*} \\
(0,54) \\
0,15 \\
(0,49) \\
-2,20 \\
(4,74) \\
0,26 \\
(5,03) \\
0,75 \\
(0,60) \\
-0,84 \\
(0,53) \\
6,84 \\
(10,3) \\
68,4^{* *} \\
(20,6) \\
99,1^{*} \\
(37,9) \\
-24,2 \\
(16,6) \\
13,2 \\
(9,75) \\
19,9 \\
(15,4) \\
-0,93 \\
(0,71) \\
0,18 \\
(0,41) \\
-26,0 \\
(27,2) \\
-140,5^{\star * \star} \\
(31,7) \\
-5,77 \\
(53,2) \\
-8,04 \\
(39,8) \\
-24,2^{*} \\
(10,8)\end{array}$ \\
\hline $\begin{array}{l}N \\
\text { F-test } \\
R^{2} \\
\text { Justeret } R^{2}\end{array}$ & $\begin{array}{r}98 \\
11,43 \\
0,106 \\
0,097\end{array}$ & $\begin{array}{r}98 \\
3,775 \\
0,495 \\
0,364\end{array}$ & $\begin{array}{r}98 \\
6,584 \\
0,0642 \\
0,0544\end{array}$ & $\begin{array}{r}98 \\
2,275 \\
0,371 \\
0,208\end{array}$ & $\begin{array}{r}98 \\
0,246 \\
0,00256 \\
-0,008\end{array}$ & $\begin{array}{r}98 \\
4,364 \\
0,531 \\
0,410\end{array}$ \\
\hline
\end{tabular}

Note: $+\mathrm{p}<0,10 ;{ }^{*} \mathrm{p}<0,05 ;{ }^{* *} \mathrm{p}<0,01 ;{ }^{* * *} \mathrm{p}<0,001$. OLS regression, Ustandardiseret betakoefficienter med deres standardfejl i parentes.

ten ikke alarmerende (VIF er på henholdsvis 3,55; 3,40 og 3,39 for denne variabel i de tre regressioner).

Umiddelbart kan det forekomme som noget af et puzzle, at valgdeltagelsen steg i sammenlægningskommunerne mellem 1997 og 2005. Stigningen kan skyldes det kortvarige fokus, som kommunalreformen gav i de sammenlagte kommuner og ikke mindst valgkampen mellem flere tidligere borgmestre om at blive borgmester i den nye storkommune. I den foregående valgperiode havde der været stor fokus på lokalpolitik, og måske følte man det endnu vigtigere at give sin mening til kende, således at ens gamle kommune (og dens kommunalpolitikere) ikke risikerede at drukne i den nye kommune.

Det er også værd, at bemærke at såvel andelen som ændringer i andelen af unge har særdeles stor betydning for ændringerne i valgdeltagelsen. Det tyder altså på, at den relative størrelse af ungdomsårgangene og ændringer deri har haft betydning for de ændringer i valgdeltagelse, vi har oplevet ved de seneste kommunalvalg og især ved kommunalvalget i 2009. Mere generelt er den samlede partielle effekt (joint effect) af henholdsvis niveauvariablene og differencevariablene betydelig. Dette implice- 
rer, at både ændringer i enkeltgruppers valgdeltagelse over tid (såsom indvandrernes faldende valgdeltagelse fra 1997 til 2009, Bhatti \& Hansen 2010) og ændringen i gruppernes komposition i de enkelte kommuner ( $\mathrm{fx}$ en lavere andel unge i Københavns Kommune) har betydning for ændringerne i valgdeltagelsen.

Tabel 3 giver ikke nogen evidens for, at valgdeltagelsen samlet set er faldet fra 1997-2009 pga. sammenlægningen af kommuner, men derimod indikerer den, at faldet fra 2005 til 2009 kan henføres til sammenlægningen. Betyder det, at kommunalreformen kan forklare det dramatiske fald i valgdeltagelsen mellem de to seneste kommunalvalg ved at den styrke valgdeltagelsen i 2005 og derefter bevirke et fald? Højst delvist. Det faktiske fald i valgdeltagelsen var på omkring 4 procentpoint (fra 69,5 procent i 2005 til 65,8 procent i 2009), mens den estimerede forskel på sammenlægnings- og ikke-sammenlægningskommuner var på omkring 2 procentpoint. Når der dertil lægges, at sammenlægningskommunerne kun omfattede under $2 / 3$ af de stemmeberettigede borgere, kan faldet maksimalt forklare 1-11/2 procentpoint af faldet (at vægte kommunerne efter størrelse øger ikke effekten). Således faldt valgdeltagelsen også betydeligt i ikke-sammenlægningskommunerne.

\section{Diskussion og konklusion}

Denne artikel stillede tre tæt relaterede spørgsmål: 1) Er der en sammenhæng mellem størrelsen på politiske enheder og valgdeltagelse? 2) Havde kommunalreformen en effekt på valgdeltagelsen? 3) Kan kommunalreformen forklare det markante fald i valgdeltagelsen mellem 2005 og 2009?

Både tabel 1 og 2 viste meget stærk evidens for en negativ ikke-lineær sammenhæng mellem kommunestørrelse og valgdeltagelse. Denne effekt består selv, når der tages højde for en lang række alternative forklaringer, der potentielt kunne være korreleret med størrelse og samtidig påvirke valgdeltagelsen. På den vis kan man sige, at en central forudsætning for, at kommunalreformen kunne betyde noget for valgdeltagelsen var til stede.

Hvad angår selve kommunalreformens effekt, viser panelanalysen på kommuneniveau i tabel 3 et tvetydig resultat. Idet sammenlægningskommunerne blev større, mens ikke-sammenlægningskommunerne stort set bibeholdt deres eksisterende størrelse, ville man forvente, at sammenlægningsvariablen var entydigt negativ i relation til valgdeltagelse. Dette var den kun for perioden 20052009. I individanalysen $i$ tabel 2 var den estimerede effekt ved at bo i en sammenlægningskommune derimod negativ og omkring 3 procentpoint. Det er nogenlunde, hvad man ville kunne forvente ud fra, hvor meget kommune- størrelsen steg over tid. Den dynamiske analyse indikerede en stigning op til reformen (1997-2005) og et meget lig fald derefter (2005-2009). Ved kommunalreformen i 1970 så man også, at valgdeltagelsen faldt kraftigt ved det andet valg efter reformen for derefter at rette sig tilbage til omkring de 70 procent ved de tredje valg. Om faldet i 1974 skyldes jordskredsvalget i 1973 eller efterdønninger af 1970 kommunalreformen, er dog umuligt at afgøre (Elklit et al. 2007). I relation til faldet i valgdeltagelsen fra 2005 til 2009 er det også værd at nævne, at faldet gik hånd $\mathrm{i}$ hånd med et kraftigt fald $\mathrm{i}$ antal af opstillede lokallister og et væsentligt fald $i$ antallet af opstillede kandidater. Tiden må vise, om vi ved de efterfølgende valg ser yderligere fald i sammenlægningskommunerne. Da der er betydelig inerti i valgdeltagelsen, kan det ofte tage adskillige valg, før en langvarig effekt slår igennem (Plutzer 2002; Gerber et al. 2003; Franklin 2004; Denny \& Doyle 2009).

Skal man stole mest på resultaterne i tabel 2 eller tabel 3 ? De har forskellige styrker og svagheder. Den statistiske individanalyse (tabel 2) er sårbar overfor uobserverede variable, som kun er et problem i tabel 3, såfremt de varierer over tid. Til gengæld gjorde individanalysen det muligt at kontrollere bedre både med flere og bedre variable og variable på individniveau end den dynamiske analyse. Hvis de variable, som tabel 2 kontrollerer for, men tabel 3 ikke gør, varierer over tid, kan det være et argument for, at tabel 2's resultater er de mest pålidelige.

Det skal understreges, at vi i analysen har fokuseret på forskelle mellem sammenlægnings- og ikke-sammenlægningskommuner. Man kan fx forestille sig at strukturdelen af reformen kan have haft en generel indflydelse på deltagelsen i kommunerne generelt. Når en effekt påvirker alle kommuner lige meget, vil den ikke blive opfanget $i$ en analyse, der ser på variationen mellem kommuner. En mulig generel effekt af reformen kunne fx være, at der samlet set er mindre på spil for vælgerne ved kommunal- og regionsvalg end tidligere, fordi kommunerne og regionerne har oplevet en strammere styring fra nationalt hold end før reformen ( $f x$ det at kommunerne ikke frit kan hæve skatterne, eller at regionerne ikke har skatteudskrivningsret).

Til spørgsmålet om hvad der har bevirket faldet i valgdeltagelsen fra 2005 til 2009, synes resultaterne fra tabel 3 at indikere, at kommunalreformen kan være noget af forklaringen, men næppe den hele. Mindskningen af antallet af valgsteder kan også have haft en betydning, om end sammenhængen mellem afstanden til valgsted og valgdeltagelse trods alt er så beskeden, er der stadig en betydelig residual at forklare. Tidligere undersøgelser viser, at faldet især er sket indenfor bestemte grupper - 
især unge og indvandrere (Bhatti \& Hansen 2010). Der er således også særlige forhold i bestemte socio-demografiske grupper, der kan have trukket valgdeltagelsen ned. En anden potentiel mulighed kan være, at valget blev afholdt ganske kort tid efter Europa-Parlamentsvalget. Ret er velkendt at kort tid mellem valg fører til faldende valgdeltagelse, idet vælgerne trættes (en faktor der ofte er søgt anvendt til at forklare USA's og Schweiz' lave valgdeltagelse - se fx Franklin 2004 for en diskussion af denne litteratur). Hvis dette er tilfældet, er der mindre grund til bekymring, idet deltagelsen sandsynligvis vil rette sig til næste valg.

\section{Referencer}

Beetham, D. 1991, The Legitimation of Power. London: Macmillan Education Ltd.

Beetham, D. 1994, „Key principles and indices for a democratic audit”, pp. 24-43. i Beetham, D. (red.) Defining and measuring democracy. London: Sage.

Bhatti, Y. \& Hansen, K.M. 2010, Valgdeltagelsen ved kommunalvalget 17.november 2009. Beskrivende analyser af valgdeltagelsen baseret på registerdata, Arbejdspapir, Institut for Statskundskab: Københavns Universitet.

Blondel, J., Sinnott, R. \& Svensson, P. 1998, People and Parliament in the European Union: participation, democracy, and legitimacy, Oxford: Clarendon Press.

Dahl, R.E. \& Tufte E. 1973, Size and Democracy, Stanford: Stanford University Press.

Denny, K. \& Doyle, O. 2009, „Does Voting History Matter? Analysing Persistence in Turnout", American Journal of Political Science, 53(1): 17-35.

Easton, D. (1965) A Systems Analysis of Political Life, New York: Wiley.

Elklit, J., Møller, B., Svensson, P. \& Togeby, L. 2005, Gensyn med sofavælgerne: Valgdeltagelse i Danmark, Århus: Århus Universitetsforlag.

Elklit, J., Svensson, P. \& Togeby, L. 2007, „Valgdeltagelse“, pp. 8198 i Buch, R. \& Elklit, J. (red.) Nye kommunalvalg? Kontinuitet og forandring ved valget i 2005, Odense: Syddansk Universitetsforlag.

Frandsen, A.G. 2003, „Deltagelse ved kommunalvalg“, pp. 109-126 i Kjær, U. \& Mouritzen, P.M. (red.) Kommunestorrelse og lokalt demokrati, Odense: Syddansk Universitetsforlag.

Franklin, M. 2004, Voter Turnout and the Dynamics of Electoral Competition in Established Democracies Since 1945, New York: Cambridge University Press.

Gerber, A.S., Green, D.P. \& Shachar, R. 2003, Voting May Be Habit Forming: Evidence from a Randomized Field Experiment, American Political Science Review 47(3): 540-550.

Hansen, M.H. 1991, The Athenian Democray in the Age of Demosthenes. Oxford: Cambridge.

Juul-Madsen, L. \& Skou, M.H. 2006, „Kan man lægge kommuner sammen uden omkostninger for lokaldemokratiet?" pp. 37-62 i Blom-Hansen, J. \& Elklit, J. \& Serritzlew, S. (red.) Kommunalreformens konsekvenser. Århus: Academica.

Kjær, U. \& Mouritzen, P.M. (red.) 2003, Kommunestørrelse og lokalt demokrati. Odense: Syddansk Universitetsforlag.
Kjær, U. 2009, „Kampen mellem land og by er i gang“, Politiken, 19. oktober 2009.

Lassen, D.D. \& Serritzlew, S. 2009, The Effect of Political Centralization on Local Democracy: Evidence from Large-Scale Municipal Reform, under udgivelse.

Løhmann, P. 2010, Lokaldemokratiet efter kommunalreformen. Har geografiske konflikter betydning for valgdeltagelsen ved danske kommunalvalg?. Upubliceret speciale. Århus: Institut for Statskundskab.

Manin, B. 1997, The Principles of representative Government, Cambridge: Cambridge University Press.

Mouritzen, P.E. 1997, „I stemmeboksen: Hvem kommer dér - og hvorfor?" pp. 262-278 i Elklit, J. \& Jensen, R.B. (red.) Kommunalvalg, Odense: Odense Universitetsforlag.

Plutzer, E. 2002, Becoming a habitual voter: Inertia, resources, and growth in young adulthood, American Political Science Review 96(1): 41-56.

Primo, D.M., Jacobsmeier, M.L. \& Milyo, J. 2007, „Estimating the Impact of State Policies and Institutions with Mixed-Level Data, State Politics and Policy Quarterly, 7(4): 446-459.

Riker, W.H. \& Ordeshook, P.C. 1968, „Theory of Calculus of Voting”, American Political Science Review, 62(1): 25-42.

Strukturkommissionen 2004, Strukturkommissionens betenkning. Hovedbetankningen. Betankning nr. 1434, Købehavn: Indenrigs- og Sundhedsministeriet.

\section{Noter}

1. En af de mest grundige politologiske kortlægninger i dansk regi er foretaget af Kjær og Mouritzen (red.) (2003), der undersøger effekten af kommunestørrelsen på en lang række variable. Generelt findes der ingen eller beskedne effekter af størrelse på borgernes følelse af tilknytning til kommunen, borgernes interesse for kommunalpolitik, borgernes kommunalpolitiske viden, borgernes politiske deltagelse mellem valgene, den politiske tillid og delvist politisk selvtillid. Hvad angår tilfredsheden med den kommunale opgaveløsning og valgdeltagelsen, findes der nogen forskelle mellem de store og små kommuner.

2. Der er i løbet af perioden sket ændringer i valgretsalderen, ligesom udenlandske statsborger fra ikke-nordiske lande fik valgret til kommunalvalg i 1981. Desuden har udvidelsen af EU også betydet, at flere kan stemme til kommunalvalgene, da EU-borgere med fast bopæl i Danmark har umiddelbar valgret til kommunalvalg (Elklit et al. 2005).

3. Vi eksperimenterede med en lineær funktionel form og det kvadrerede antal indbyggere, som begge gav en langt svagere sammenhæng

4. Nogle 2005-informationer er aggregeret fra kommuneniveausinformationer for gamle kommuner. Dette medfører lidt støj i regressionerne for de kommuner, der blev delt ved reformen. Der er dog ingen grund til at tro, at støjen ikke er tilfældig, og hovedresultaterne er da også robust overfor at ekskludere de opdelte kommuner.

5. Da 2005 og 2009 regressionerne bygger på 98 kommuner, mens 1997 og 2001 bygger på 275 kommuner er det generelt sværere at opnå signifikante effekter ved de to seneste valg, og det betyder også at koefficienterne er mindre robuste ved de to seneste valg end valgene i 1997 og 2001. Med relativt få observationer, som $275 \mathrm{og}$ 98 er, er det også svært at inddrage mange forklarende variable i samme model, da de fx kan give mulitikollinearitets problemer. I de nuværende modeller, holder de beregnede VIF-niveauer sig på under 10 for alle variable (og betydeligt lavere for indbyggertalsvariablen).

6. Effekterne er ikke vist for de faktorer, der består af flere variable fx et første og et andengradsled, eftersom effekterne for disse skal tolkes i sammenhæng. 
7. Vi eksperimenterede med en proxy for afstand til valgsted i tabel 1 . Antal stemmeberettigede pr. valgsted og antal valgsteder pr. km2 i kommunen. Som forventet var der en negativ sammenhæn mellem variablene og valgdeltagelsen, om end variablene ikke var statistisk signifikante.
8. For nogle 1997, 2001 og 2005 variable har det været nødvendig at aggregere data ud fra information på præ-reform kommuneniveau. Jf. note 4 burde dette ikke give anledning til bias i estimaterne, som er robuste overfor at ekskludere de berørte kommuner, som blev delt i sammenlægningsprocessen. 